\title{
Covid-19: junior doctor calls on colleagues to gather supplies for staff working long hours
}

\section{Abi Rimmer}

The BMJ

A junior doctor has called on her colleagues to gather supplies that will help healthcare professionals working long hours during the covid-19 outbreak.

Josie Cheetham, chair of the BMA's Junior Doctors Committee in Wales, shared on Twitter the details of a supply box that she had put together for doctors who were too tired to travel home. "It contained supplies typically needed after/between work shifts, when staff unexpectedly need to stay on site between shifts," she wrote. "My hope was that the box allows doctors to meet personal hygiene needs and rest well despite their unplanned stay on site."

Cheetham said that a similar supply box would be helpful for staff working during the covid-19 outbreak. It contains items including antiperspirant, toothpaste, toothbrushes, shower gel, eye masks, and ear plugs.

"We don't know what our working patterns will look like during the coming months yet," she said. "But preparing for staff needing to meet personal hygiene needs and rest on site could be one way we as a community can prepare."

She said that it was important to look after the basic needs of healthcare staff, as they were key to the covid-19 response. "We can make a difference to this as a community," she said. "Promoting healthcare professionals' physical and mental wellbeing leads to sustained safer and higher quality care: we are humans."

\section{Positive response}

The post has received a positive response from doctors on Twitter. Laura Muirhead, a specialist registrar, commented,
"This is great. Having gone round the wards at 2 am looking for a toothbrush on multiple occasions this kind of initiative would be amazing."

Philip Banfield, chair of the BMA Welsh Consultants Committee, said, "There'll be a need to rally round and care for each other like never before. Staff need looking after-proper food and fluids 24/7; rest facilities; and care for kids." 3

Others said that they had already done something similar to Cheetham. Emma Shircliff, a junior doctor, said, "I've made a similar box [containing] tampons and pads, toothbrushes and toothpaste, pot meals, some sweets, spray deodorant, and 2-in-1 shampoo. Hoping it's overkill!"

Lailah Peel, chair of the BMA's West of Scotland Regional Junior Doctors Committee, said that doctors in Scotland have had access to BMA Scotland care boxes since December. ${ }^{5}$ These boxes contain basis supplies such as snacks, tea bags, coffee sachets, and socks. ${ }^{6}$

Cheetham J. Twitter. 15 Mar 2020. https://twitter.com/drjosiech/status/ 1239248499230887937.

Muirhead LJ. Twitter. 15 Mar 2020. https://twitter.com/ljmuirhead/status/ 1239324779045433344.

3 Banfield P. Twitter. 15 Mar 2020. https://twitter.com/DrPhilBanfield/status/ 1239256432945569805 .

4 Shircliff E. Twitter. 15 Mar 2020. https://twitter.com/emma_shircliff/status/ 1239297287718871040.

5 Peel L. Twitter. 15 Mar 2020. https://twitter.com/lailahpeel/status/1239266308212043777. BMA Scotland. BMA Scotland, caring for you this Christmas and beyond. 15 Dec 2019. https://bmascotland.home.blog/2019/12/15/bma-scotland-caring-for-you-this-christmasand-beyond/.

Published by the BMJ Publishing Group Limited. For permission to use (where not already granted under a licence) please go to http://group.bmj.com/group/rights-licensing/ permissions 